\title{
The Implications and Relevance of a Tax Exemption for Co- operatives: The Case of a Small European State
}

\author{
Submitted 14/05/19, 1st revision 09/06/19, Accepted 24/07/2019 \\ Peter J. Baldacchino ${ }^{1}$, Julia Portelli² Simon Grima ${ }^{3}$
}

\begin{abstract}
:
Purpose: To assess the relevance of the tax exemption being granted to Maltese cooperatives on their ploughed-back profits to the creation of such legal structures and to their financial performance.

Design/Methodology/Approach: We do this by carrying out 21 semi-structured interviews and reviewing of the financial statements of four co-operatives over a period of five years.

Findings: Results show that such a tax exemption may indeed be attracting a few applicants to form co-operatives. However, although the exemption may be serving as an incentive to encourage such start-ups, their promoters may be commonly lacking more valid reasons for choosing to set up this particular structure, which is meant to balance both commercial and social goals. The article therefore concludes that the tax exemption on its own is evidently insufficiently effective in the promotion of genuine and financially successful start-ups and recommends that a review of the tax exemption provision is likely to be beneficial. Further recommendations include (i) rendering such a provision more relevant by linking its granting to the results of a social audit for each co-operative,(ii) reviewing the legal asset-lock provision so as no longer to undermine the attractiveness of the tax exemption, and also (iii) launching vigorous education programmes on the raison d'etre of a co-operative.

Practical Implications: Although there were several studies relating to Maltese cooperatives, there has not been a study specifically dealing with the tax exemption for such entities. Accordingly, this research study would prove to be useful in assessing the relevance of the tax exemption conceded to Maltese co-operatives by delving into its implications.

Originality/Value: This study will identify any possible amendments that could be made to resolve the tax implications encountered.
\end{abstract}

Keywords: Co-operatives, tax exemption, tax implications, asset lock, start-ups, Malta.

JEL Codes: H2, H21, J54, Q13.

Article Type: Research study.

\footnotetext{
${ }^{1}$ Head and Associate Professor, Department of Accountancy, Faculty of Economics, Management and Accountancy,University of Malta, peter.j.baldacchino@um.edu.mt

${ }^{2}$ Graduate Accountant, Department, Faculty of Economics, Management and Accountancy, juliaportelli@gmail.com

${ }^{3}$ Head and Senior Lecturer, Insurance Department, Faculty of Economics, Management and Accountancy, corresponding author, simon.grima@um.edu.mt
} 


\section{Introduction and Background}

The International Co-operative Alliance (ICA) defines a co-operative as: „an autonomous association of persons united voluntarily to meet their common economic, social and cultural needs and aspirations through a jointly-owned and democratically controlled enterprise" (ICA, 1995, p. 1). The Constitution of Malta (1964, p. 9) lists in Article 20 the encouragement of co-operatives as one of the fundamental principles to which the State must adhere. Over time, the Maltese Government offered direct financial support, as well as fiscal incentives, in an attempt to solidify and promote the co-operative movement. One such form of enticement to Maltese co-operatives was the introduction of a tax exemption in 1965, as a means to incentivise the setting up of more co-operatives (Galea, 2012). In this regard, Maltese co-operatives became exempt from paying income tax on any surplus made (Income Tax Act, 1949).

The tax exemption provided co-operatives with a rather advantageous position over other forms of legal entities. In the light of the fiscal backup provided to cooperatives, they have been broadly successful, albeit not exactly problem-free (Delia, 2006). In particular, the tax exemption brings with it a number of implications. This is evident by the fact that despite the introduction of the tax exemption on ploughedback surpluses, it did not lead to the desired effect, since the number of co-operatives registered in Malta did not increase significantly (Galea, 2012).

Although, there were several studies relating to Maltese co-operatives, to date, there has not been a study specifically dealing with the tax exemption for Maltese cooperatives. Accordingly, this research study would prove to be useful in assessing the relevance of the tax exemption conceded to Maltese co-operatives by delving into its implications. Moreover, in this study we will identify any possible amendments that could be made to resolve the tax implications encountered. Therefore, our objectives are:

- to ascertain the regulatory framework relating to the tax exemption for Maltese co-operatives;

- to assess the relevance of the tax exemption for Maltese co-operatives by:

$>$ examining the extent to which such exemption has encouraged startups; and

$>$ analyse the application to date of such exemption for co-operatives and its link, if any, to their financial performance; and

- to evaluate whether, and to what extent, if any, the tax exemption provision is providing the potential support to co-operatives.

Ultimately, the use of Malta in this research as a case study is relevant because it is the first such study for Malta, making it important for the Maltese economic, fiscal and regulatory development. Moreover, the use of small countries as laboratories for more complex politics, economic and corporate governance policies of larger 
countries has been carried out by various researchers such as Briguglio (1995), Baldacchino (2017), King (1993) and Bezzina et al. (2012) and (2013).

\section{Methodology}

To do this, we carry out semi-structured interviews with co-operative representatives, government representatives, and specialists in the field of taxation and co-operatives. The semi-structured interviewing process was deemed the most appropriate since it ensures that similar data is collected from the interviewees, yet it allows a degree of flexibility. Purposive sampling was used to identify and select the research participants in line with their ability to form an understanding of the research topics. We held the interviews, during the period between October 2017 and March 2018, and continued until the data saturation point was reached, that is at 21 interviews. That is the point when the collected data was perceived to give no further added value.

The interview schedule was designed to include a set of key questions thus ensuring that salient themes were covered, whilst enabling us to add impromptu questions to expand our understanding of the respondents' insights. The resulting interview schedule consisted of five closed-ended statements to which a dichotomous scale was utilised and eight open-ended questions which requested the interviewees to provide their opinion and add further comments.

We also carried out a review of the financial statements of a sample of different types of Maltese co-operatives, excluding social co-operatives. Sets of abridged financial statements for each of the co-operatives for four reference years were obtained. The headline figures for each co-operative for every year were cited and tables were also built. Additionally, where possible, four main items were extracted:

- Net surplus before distribution;

- Patronage refund;

- Patronage refund vis-à-vis Net surplus before distribution;

- Tax amount being paid.

A profile was compiled on the application to date of the tax exemption and its link, if any, to the financial performance of each of the four co-operatives to enable comparison at the Findings and Discussion stage.

\section{Findings and Discussions}

\subsection{The Maltese Regulatory Framework}

To ascertain the Maltese regulatory framework, a review of the available relevant statutes together with any proposed amendments was carried out, with a particular focus on the tax exemption for Maltese co-operatives. In this regard, it may be 
pertinent to note that the Co-operatives Societies Act (CSA) needs to be updated to reflect the changes in social and economic realities, which have occurred since its last revision in 2001. Both co-operative associations have pointed out the need for such an Act to be updated, given that the current regulatory framework is evidently no longer fulfilling today's needs of the Maltese co-operatives. Furthermore, it may be noted that the Income Tax Act (1949) may also need to be amended since currently Maltese co-operatives are unable to claim tax credits upon a distribution of dividend from a subsidiary limited liability company (LLC) to a co-operative. This issue was also evident from the review of financial statements carried out.

\subsection{The Relevance of the Tax Exemption for Maltese Co-operatives}

\subsubsection{Does the tax exemption for Maltese co-operatives need to be reviewed?}

The tax exemption for Maltese co-operatives was introduced during a period of time when the government provided a lot of support, but this is not so much the case in recent times. Since Malta's accession to the European Union (EU), such assistance has been decreasing or taking on an indirect form. The EU Member States which exempt co-operatives from the application of income tax are in the minority, since most do not provide co-operatives with special tax incentives. Therefore, it may be timely to review the tax exemption to evaluate whether it is still up-to-date and relevant to the needs of Maltese co-operatives.

\subsubsection{To what extent has the tax exemption encouraged Maltese co-operative start-ups? Is it the only way to attract them?}

Most respondents consider the existing tax exemption to be a major incentive for the formation of Maltese co-operatives. Their reasoning has more to do with cooperative start-ups rather than for the sustainability of co-operatives, since they believe that the tax exemption serves more of an incentive to co-operative start-ups rather than for their sustainability.

However, participants noted that, the tax exemption attracts a number of individuals who are interested in setting up a legal entity, since it is their belief that the tax advantage is a major consideration in establishing a co-operative rather than a LLC. Nevertheless, there are more valid reasons why a number of individuals may opt to set up a co-operative rather than a LLC, including the co-operative model per se and the one-member-one-vote system.

In principle, a tax exemption per se is always an incentive to attract individuals, specifically, because they would be drawn to the desirable concept of being exempted from paying income tax. Therefore, the idea of exempting co-operatives from income tax has its attraction and is thus useful. However, it is not the only incentive that is needed, since the number of registered co-operatives in Malta is as yet relatively low when compared to other types of legal entities. 
One important factor emanating from this study is that there is not is not much awareness of the tax exemption for Maltese co-operatives and how to make use of it. Educational campaigns in this regard are evidently very limited, resulting in a lack of familiarity and awareness of the co-operative model and the tax exemption. Education should not be restricted to tax only, but should also clarify on how tax fits in the overall co-operative model.

Co-operative start-ups may need other support besides the tax exemption. They may need assistance which is not necessarily fiscal. For example, they may need help on how to fill in certain forms, consultancy and professional services, financial support, training and development. This non-fiscal support need to go hand-in-hand with the fiscal one. It has been noted that there are a number of co-operatives that encounter problems when trying to obtain bank loans and other financing, due to banks being more reluctant to finance co-operatives as opposed to financing other legal entities. This perception is therefore probably discouraging the formation of Maltese cooperatives. In this context, the Central Co-operative Fund (CCF) may fill in such a gap by granting loans to co-operatives, possibly at a subsidised interest rate.

Moreover, since Maltese banks are prohibited from forming into a co-operative, by Article 5 of the Banking Act (1994, p. 11), which states that only companies can form a bank, a concurrent solution could be that of amending the Banking Act to allow for the establishment of co-operative banks.

\subsection{The Application to Date of the Tax Exemption}

\subsubsection{Is the tax exemption for Maltese co-operatives encouraging sham co- operatives?}

In a publication on the future of co-operatives, Delia (2004) commented that Maltese co-operatives have existed for a long number of years, but it is timely to analyse the way they have been operating. Maltese co-operatives need to be assessed with a view to whether they are really behaving like co-operatives, or if they are just there for tax avoidance reasons. Furthermore, Delia (2006) explained that there are various cooperatives claiming to belong to the 'co-operative class', yet they differ in their core objectives, as well as in the means to achieve such objectives. In fact, most respondents acknowledged the possibility of existing sham co-operatives, the main purpose of which could easily be tax avoidance. In Maltese legislation, there has been a consistent trend for a reduction in the minimum membership requirement to set up a co-operative. Despite that the original intention behind the reduction in the number of members seems to have been the encouragement of new co-operative start-ups, interviewees acknowledged that, at the same time, this has made it more possible for sham co-operatives to be established.

Nevertheless, the argument as to the relevance of the statutory minimum membership requirement to set up a co-operative considering the possibility that sham co-operatives are set up, seems to be invalid reasoning. Although, one can 
argued that it is relevant since the lower such minimum number is, the higher the possibility that a sham co-operative could be established, if the regulator performs satisfactory due diligence procedures on a continuous basis, one can establish legitimacy. Therefore, it is probably more relevant to focus on the level of due diligence being performed by the regulator at the start-up phase because, at that stage, sham co-operatives could be easily stopped if a rigorous exercise were to be performed.

\subsubsection{Should co-operatives be exempt from tax in return for the social benefit that they provide? What role can social audits play?}

Co-operatives are formed "to meet their economic, social and culture needs and aspirations" according to Article 21(1) of the CSA (2001). Co-operatives, besides nurturing their commercial values, aim to achieve ethical and co-operative values, as listed by the ICA. In fact, Ellwood (2012) states that: „, Co-operatives show there is another way of organising the market where profit is not the sole objective and where, theoretically, fairness is institutionalised and people are the centre of decision-making. Co-operatives' attitude towards social values is challenging the hyper-competitive, winner-takes-all model of corporate capitalism" (Ellwood, 2012).

Co-operatives worldwide commonly operate according to the same seven core principles adopted by the ICA to promote compliance to the ethical and co-operative values. Prakash (2003) argues that co-operatives ought to be judged on the extent to which they adhere to the seven principles. This can be done through a social audit, which is the process whereby a co-operative can account for its social performance, report on and improve that performance. Such a process could assess the cooperative's contribution for the improvement of the status to its members' economic needs as well as its social needs, including the community where it operates. Both co-operative associations in Malta agreed on the proposed amendment regarding the introduction of a social audit (Koperattivi Malta [KM], 2014 and MCF, 2014). A social audit for co-operatives may include a main objective of judging whether, and to what extent, a co-operative is eligible for tax exemption and other support.

Respondents questioned the notion of exempting co-operatives from tax in return for the social benefit to society that they provide. In theory, the co-operative model is different from other types of legal entities. By nature, the co-operative model is more socially oriented, there being less quest for profitability and more hands-on involvement of all the co-operative members, making the business model overall more democratic and socially beneficial. Consequently, this is a business model which any administration would do well to promote and, therefore, it may be argued that co-operatives ought to be exempt from tax.

However, in practice, the extent to which individual co-operatives provide any substantial social benefit is debatable. A number of co-operatives may not be providing a social benefit at all. One possible way to ameliorate this situation is to 
judge co-operatives on whether they are eligible for the tax exemption and the extent to which they can be exempted, based on a periodic social audit. The introduction of social auditing would render a co-operative accountable for its social performance and the extent to which it is improving that social performance.

The social auditor would have a checklist to help assess the extent to which a cooperative is adhering to the co-operative values and principles. This is a process intended to assess the co-operative's contribution for the improvement of the status, not only with regards to its members' economic requirements, but also with regards to social requirements and those of the community in which it operates. The support of the co-operative to all the co-operative principles (CPs) is validated by such a social audit.

The introduction of social auditing for Maltese co-operatives has long been debated. Those in agreement claimed that this is crucial to help institutions assess the extent to which a co-operative's practices are in line with co-operative values and principles. The eligibility of a co-operative for tax exemption and related support could be tied up to the results of a social audit, which would indicate how far the Corporate Principles (CPs) are being fulfilled.

The benefits of social auditing are various. However, one clear relevance is that the results of the social audit can be used one way or another to determine the extent to which a co-operative is entitled to fiscal support. This has the noble purpose to encourage co-operatives to promote their social element, and also to concurrently discourage the emergence of sham co-operatives.

\subsection{Supporting Co-operatives}

\subsubsection{Government Aid and Co-operatives}

It may be argued that it is the role of national institutions to embark on activities offering support to co-operatives, helping to build successful and sustainable cooperatives, while nourishing and nurturing individual co-operators in going about their daily business (ICA, 2013). KM (2010) noted that by assisting co-operatives in Malta, such as by providing a tax exemption for co-operatives, the government could reap various benefits, including an increase in employment opportunities, the ongoing provision of lifelong learning, education and training to co-operative members and their employees, an increasingly flexible workforce, a decrease in the flow of profits out of the local economy, and a far more equitable distribution of wealth.

Juhász (2004) stated that despite that the relationship between Maltese co-operatives and the government will always remain vital, co-operatives should be considered to be autonomous organisations, with the government merely acting on creating the general framework conditions required so that co-operative autonomy, self-financing and self-reliance are supported. This was further evident in the dissertation by Agius 
(2013), whereby the author stated that the Maltese co-operative movement needs to enter a new era where, ironically, the government's role would be essential. Such role would not necessitate the creation of co-operatives, but the environment which would enable co-operatives to flourish. The government needs to take on-board the co-operative model, not for control's sake, but for the enhancement of economic growth.

Juhász (2004) stated that from a business point of view, the co-operative model in Malta is still considered to be weak. This makes it evident that without institutional and managerial strengthening, Maltese co-operatives may not be able to survive liberalised market conditions. Considering this, it is debatable whether Maltese cooperatives could operate sustainably without government aid, such as the tax exemption provision.

Delia (2006) commented that co-operatives are intended to be autonomous and independent enterprises, but they may not be so, for numerous historical reasons. They might have relied for too long on government support, which set up is not conducive of a healthy institution.

\subsubsection{Should co-operatives be supported?}

Whether or not the government should provide support to co-operatives is a moot point. Respondents, on the one hand, argued that the government is under no obligation to provide support to co-operatives. Besides, since the fourth $\mathrm{CP}$ advocates "autonomy and independence", co-operatives are expected to be independent rather than, in the words of one interviewee, acting as "parasites" of government support.

On the other hand, it may be argued that the benefits to be reaped by assisting cooperatives makes it worthwhile for the government to provide such support to cooperatives. In the Maltese scenario, government support in this regard is important because the co-operative sector is still, as yet, a small sector in need of growth. Therefore, providing government support to promote the growth of the Maltese cooperative sector could result in various potential benefits.

\subsubsection{Should the tax exemption for Maltese co-operatives be limited?}

While it may be said that the tax exemption may serve as a major incentive for encouraging co-operative start-ups, such exemption may also give rise to a possible conflict with regard to competition law, in that it may not permit a level-playing field for all forms of legal entities to operate and compete alongside each other. This is evident by the fact that while LLCs in Malta pay a corporate income tax rate of $35 \%$ on any profit made, co-operatives are exempt from such a payment due on any surplus made. Paragraph 7(2) of ILO R.193 illustrates a legal principle of equal treatment, namely that: „Co-operatives should be treated ...on terms no less favourable than those accorded to other forms of enterprise. Governments should 
introduce support measures for the activities of co-operatives that meet specific social and public policy outcomes " (ILO, 2002).

This possible conflict may be resolved by limiting the tax exemption for Maltese cooperatives through various ways. In this regard, it is important to establish a sensible balance between the objectives of co-operatives and operational requirements on one side, and respecting competition law on the other side (Fabri, 2006). Methods of limiting the tax exemption for Maltese co-operatives may include limiting the tax exemption to a fixed number of years only or else by setting a tax exemption ceiling. The latter may be based on a threshold either on a co-operative's gross profit margin, or on its Reserve Fund, or both.

Article 90(3) of the CSA (2001) provides for the establishment of the Reserve Fund. A Maltese co-operative is obliged to transfer a minimum of $20 \%$ of its annual surplus to this fund, until the fund is equal to "the total of the paid-up share capital and of twenty per cent of the borrowed capital of the society" with the monies being held by the enterprise in liquid form to cater exclusively for past or future losses. The Reserve Fund has a significant role in safeguarding against insufficient liquidity (Münkner, 2010; Henrÿ, 2012).

The tax exemption privilege may have a ceiling based on this Reserve Fund. When a co-operative's accumulated mandatory reserve fund reaches a certain threshold, the co-operative may no longer be tax exempt (Arado, 2017). A tax exemption ceiling could potentially make sense because the purpose of the tax exemption is to help a co-operative become sustainable. Once a co-operative becomes sustainable, then it would no longer require the tax exemption. It is indeed positive that co-operatives are offered government support, such as in the form of a tax exemption, as long as such support does not become counter-productive. Going forward, co-operatives cannot rely on government support, whether indefinite or permanent. They need to be able to get their business running and be self-sustainable. Hence, limiting the tax exemption to a number of years could potentially make sense. In such case, the tax exemption would still serve as an incentive for the formation of new co-operatives.

On the same concept, some interviewees commented that if the tax exemption were to be available for the first five years only, co-operatives could be set up only temporarily for the sake of benefitting from such an exemption. This problem however, can be avoided through appropriate monitoring and supervision by the regulator. If it is a genuine co-operative providing a social element and, at the same time, being financially viable, it does not make sense for such a co-operative to liquidate itself merely because of the five-year period of tax exemption. No genuine co-operative with strong social and financial elements would consider seriously liquidating on the basis that the tax exemption has been terminated. 


\subsubsection{Is the 5\% contribution to the CCF another form of tax?}

While co-operatives are exempt from income tax, co-operative legislation establishes a statutory fund to which every co-operative generating a "surplus resulting from its activities, operations, investments and any other sources at the end of each accounting period" (CSA, 2001, p. 35) must contribute 5\% therefrom. The contribution to the CCF is not a tax or any other fiscal obligation imposed on cooperatives (Fabri, 2006). Its role is to promote the solidarity objective. This being the basic characteristic of the co-operative model. This is accomplished by advocating co-operative education, training, research, audit and the general progress of the cooperative movement in Malta, as per Article 3 of Subsidiary Legislation 442.03.

Unfortunately, Maltese co-operatives eligible to contribute to the CCF are often reluctant to make the payments due, since they tend to view the 5\% contribution as just another tax imposition weighing down on them (Fabri, 2006). Baldacchino et al. (2017) noted that, in theory, the CCF was meant to bring diverse co-operatives closer to each other, being based on the community concept of the stronger helping the weaker. However, a bleak reality was exposed when some interviewees blamed the $\mathrm{CCF}$ for being the main source of the clashes existing in the co-operative movement. Considering this, Baldacchino et al. (2017) questioned whether there ought to be a complete elimination of the CCF. The possibility of the CCF helping to finance cooperatives is yet not properly utilised. In fact, Baldacchino et al. (2017) emphasized that funds approved by this Fund need to be monitored more strictly in the best interests of the co-operative movement.

Half of the respondents believed that Maltese co-operatives are not really tax exempt because they are obliged to pay $15 \%$ withholding tax upon any distributions of surpluses, as well as an annual 5\% contribution of any surpluses made to the CCF. The accumulation of the money in the CCF does not go into the government's consolidated fund, but belongs to co-operatives themselves. However, many cooperatives are not benefitting from such funds and this may be the reason why this $5 \%$ contribution is generally being viewed as just another tax imposition. This behaviour shows a lack of solidarity, which may be due to the reputation perceived by co-operatives with regards to the CCF that it is not managing its funds well. Whether to maintain the $5 \%$ contribution to the CCF or not, could be tied up to whether the tax exemption is to be maintained or not. If the tax exemption were to be limited to a definite period, then it may be argued that the 5\% contribution to the CCF ought to be eliminated once co-operatives start paying income tax on any surplus made, to remove any excessive financial burden imposed on co-operatives.

This suggested solution would not see an end to the CCF since co-operatives would still contribute to the CCF when they are eligible to benefit from the tax exemption provision. As a result, the CCF would be able to focus more of the support it could provide on co-operative start-ups. 
An even more radical solution would be the complete elimination of the $5 \%$ contribution to the CCF, as suggested by some interviewees. The various issues in the movement were deemed to have been brought about because of the CCF. Thus, an overhaul of the CCF could potentially make sense. In such a case, some alternative measure to ensure solidarity among co-operatives would need to be introduced.

\subsection{The Tax Exemption and the Financial Performance of Co-operatives}

\subsubsection{Distribution of Surpluses and Taxation payable}

Article 2 of the CSA (2001, p. 3) defines surplus as "net income less expenditure", which allows only the distribution of the net surplus, following obligatory transfers from the total surplus to the CCF and the Reserve Fund (Article 92, CSA). Distributions are allowed in a variety of methods. Nevertheless, the most common types of surplus distribution are patronage refunds, with bonus shares and certificates being identified as the least used methods (Baldacchino and Camilleri, 2013). As a consequence of the tax exemption for co-operatives, there can be unfair tax treatment on those co-operative members receiving a distribution.

Since co-operatives are exempt from paying income tax, surpluses made are allocated to the Untaxed Account. When there is the issue of a distribution made from the Untaxed Account to the members of a co-operative, the said members are obliged to pay $15 \%$ withholding tax. However, unlike company shareholders, they cannot utilise the full imputation system (KM, 2010).

Besides, the CSA currently does not allow for the distribution of surpluses from previous years purposely put aside for investment purposes, except for special cases such as on liquidation of the co-operative. This limitation, referred to as the 'assetlock provision', creates an automatic imposition on management to distribute all surpluses to its members at the end of each financial year (KM, 2010).

\subsubsection{Is the tax exemption relevant to the financial performance of co- operatives?}

After carrying out a review of the financial statements, we noted that the tax exemption is only relevant to the financial performance of a co-operative if the surplus is ploughed back into the co-operative. It is only on the ploughed-back surplus that no income tax is payable. If there is a distribution of the surplus, then income tax becomes liable. Accordingly, the tax exemption is beneficial to a cooperative, which is interested in making an investment with the aim of expanding. One may therefore say that the tax exemption is advantageous to co-operatives, which plough back the surplus because they are not required to pay income tax upon it.

On the other hand, other co-operatives which distribute their surpluses benefit only partially from the taxation system of Maltese co-operatives, since they only pay a 
withholding tax of $15 \%$, rather than a full corporate income tax rate of $35 \%$, and this is because tax becomes payable upon a distribution of such surplus. Although there is indeed the advantage of ploughing back the surplus without paying taxation upon it, there is nevertheless the adverse side of the asset lock to be considered whenever such plough-back occurs. Such asset lock is commonly interpreted as resulting whenever the yearly surplus is not distributed in the year in which it is earned. In this case, surpluses are assumed to be asset locked and therefore cannot be distributed in later years. This is on the basis that Article 92 of the CSA refers exclusively to surpluses earned during that "accounting period" for distribution purposes. Given such restrictions, co-operative members are discouraged from opting to plough back surpluses within the entity, despite any temporary tax exemption with which that they may be tempted.

Therefore, the tax exemption may be viewed as a double-edged sword because, on the one hand, if the surplus is retained for investment and the tax exemption is availed of, then such surplus cannot be distributed directly to the co-operative members in later years because it then becomes locked. On the other hand, if the surplus is distributed, the tax exemption cannot be fully availed of, and this is because withholding tax becomes payable. While keeping the aforementioned aspects in mind, it may be argued that it is not that much of a tax exemption, considering that the price of ploughing back the surplus to take advantage of such an exemption is that the co-operative members cannot receive such money back in later years.

A few interviewees noted the need for the current system to be amended, so that cooperatives can distribute the surplus made at any time without any restrictions to distribution, in the same manner as in LLCs. This would necessitate the elimination of the implied asset lock. However, whether it is better for the asset lock to be removed remains a controversial issue. A counter-argument to insisting on the asset lock is that such asset lock is perceived as being in line with the identity of cooperatives, which places more emphasis on resources being retained for future generations.

The law in force today dates to 2001, and one must keep in mind that, in 2001, few co-operatives in Malta were making surpluses and, therefore, the question of ploughing back surpluses to future years arose much less frequently. Yet today, more and more co-operatives are aiming to register surpluses and, therefore, the asset lock issue tends to arise much more frequently. Besides the asset lock issue, there is also the matter of unfair tax treatment in the case of a co-operative, which owns a subsidiary LLC. Amendments may also be required to the provision in the Income Tax Act (1949) which deals with tax credits on dividends received from subsidiary LLCs. Because of their tax-exempt status, co-operatives are unable to claim a tax credit, meaning that upon a distribution of dividend from a subsidiary LLC to a cooperative, there would be an overcharge of taxation on the same income. 
A possible solution to the matter of unfair tax treatment could be to extend the taxexempt status to the case of a distribution of such a dividend. Besides, if such an extension were to be limited to dividends received from subsidiary co-operatives rather than LLCs, this would promote the setting up of co-operative groups in Malta. Currently, there is only one such co-operative group in existence. This issue of unfair tax treatment could be the reason as to the lack of co-operative groups in Malta.

\section{Conclusion and Recommendations}

Therefore, we can conclude that, the Maltese regulatory framework is determined by the CSA (2001). It was ascertained that this framework for Maltese co-operatives tends to be paternalistic. It is a framework which needs revision, considering that it is a law which has been going on for 18 years. In particular, the tax exemption has been there from the beginning and it has never been reviewed.

Overall, respondents conceded that the existing tax exemption serves as an incentive in encouraging co-operative start-ups. However, some asserted that there are more valid reasons why a number of individuals may choose to set up a co-operative rather than a LLC, including the co-operative model per se and the one-member-onevote system. Nonetheless, the current system seems to be falling short of expectations in terms of its effectiveness and this could be one of the main reasons why the movement did not grow that much.

As regards the application to date of the tax exemption, it was found that such exemption may have attracted applicants forming a co-operative merely for them to avail themselves of such an exemption, rather than because they had any deep interest in the co-operative values and principles. On this subject, a number of participants referred to sham co-operatives, that is, co-operatives, which were not true to the nature of genuine co-operatives. In this regard, the setting up of such cooperatives could be prevented by the introduction of social auditing and more stringent regulations. With respect to the link between the tax exemption and the financial performance of Maltese co-operatives, it was found that such exemption could be much more effective in the case of successful financial performance, if the asset-lock provision at present being generally implemented is dealt with accordingly.

In the current context, despite the tax exemption provision, co-operatives generally seem to prefer to distribute the surplus made, rather than ploughing it back. This is due to the concern of their members that the ploughed-back surpluses would be forfeited to future generations, further compounding their concern that they would lose any ownership claim on such ploughed-back surpluses in future distributions.

Overall, respondents acknowledged that the tax exemption is relevant for Maltese co-operatives, yet on its own, it is insufficient for the promotion of co-operatives. The need for further support was evident, but this was not necessarily fiscal. It could 
include a restructuring of the $\mathrm{CCF}$ or, at least, better re-distribution of its financial resources. Furthermore, a review of the whole regulatory framework led by the CSA, which was enacted in 2001, is called for.

Therefore, a review of the tax exemption for Maltese co-operatives is likely to benefit them. The present tax exemption on its own is evidently insufficiently viable in encouraging new co-operative start-ups. Less regulatory paternalism and more freedom for individual co-operatives to operate autonomously within the current framework could also render the tax exemption to be more effective.

Unless each individual co-operative is left to its own merits for sustainability, it will not thrive in the competitive corporate environment, despite the tax exemption. This does not mean that no support is to be provided for co-operatives, but that such support needs to be designed and applied in such a way as to achieve its objective of helping towards the eventual sustainability of the enterprise.

It may be important for such support to continue to be extended to co-operatives, given their relative vulnerability vis-à-vis LLCs. Nonetheless, the tax exemption may, for example, be combined with other forms of support and not necessarily be conceded on a permanent basis and for this it is necessary to balance between support and independence an update the law. Moreover, we suggest:

a) that vigorous co-operative education programmes are launched with a view to promoting co-operative ideals and practices.

This may be achieved through (i) more emphasis being placed on co-operative development by the public authorities in line with Article 20 of the Constitution of Malta (1964, p. 9); (ii) case studies on successful local and foreign co-operatives being promoted by the regulator or respective associations; and (iii) specific cooperative courses being launched particularly by the education centres and Universities.

b) that the statutory minimum membership requirement to set up a co-operative be reduced to three members.

In addition to the tax exemption, the reduction in the minimum threshold would aid in encouraging the formation of co-operative start-ups. The present threshold of five members could serve as a barrier due to co-operatives finding it difficult to meet this statutory requirement. This is subject to maintaining robust regulatory measures to ensure the restriction of registration of new co-operatives to genuine ones.

c) that a social audit for each co-operative is conducted with the main objective of judging whether, and to what extent, it may be eligible for tax exemption and other support. 
The introduction of social auditing would render a co-operative accountable for its social performance and the extent to which its actions are upholding its identity as a co-operative. The result of such an exercise would include eligibility, or otherwise, for tax exemption and related support.

d) that the tax exemption for Maltese co-operatives be limited to a specific period.

The first few years of operations are crucial for a co-operative start-up. Therefore, the tax exemption is relevant for a co-operative start-up if it is to be incentivised to plough back its surpluses with the aim of growing its business. However, a period limitation is also to be stipulated to ensure the ultimate independent sustainability of such an entity and the fulfilment of its corporate citizenship responsibilities.

e) that the 5\% contribution to the CCF be eliminated if co-operatives are no longer tax exempt after the elapsing of a certain period of time.

If co-operatives become taxable after the elapse of a certain period in line with (d), while the 5\% contribution to the CCF still stands, then their financial commitments towards the community could be seen to be excessive. Therefore, one way out of this would be to remove the obligation to pay such 5\% contribution once the normal tax starts to be payable.

\section{f) that the system of CCF funding be overhauled.}

An even more radical measure than that stated in (e) could be the elimination of the $5 \%$ compulsory funding for all co-operatives, irrespective of their existing tax position. However, this might need to be a long-term measure since, if the 5\% contribution to the CCF were to be removed, it would probably need to be replaced by some alternative measure to ensure solidarity among co-operatives in line with the sixth $\mathrm{CP}$, which promulgates "Co-operation among co-operatives".

g) that the asset-lock provision be reviewed in such a way that it does not undermine the attractiveness of the tax exemption provision.

The way the asset-lock provision is currently being interpreted is that once surpluses are ploughed back, they then become automatically non-distributable, even if left for the subsequent year only. Financially, this is probably unnecessary, if not even damaging, in that such an interpretation could easily undermine any incentive to plough-back surpluses being made by the tax exemption provision.

However, since ensuring the long-term sustainability of the co-operative is related to one of the CPs, namely "Autonomy and Independence", a balance needs to be found between distributable and non-distributable surpluses and the current asset-lock provision should not be universally and automatically applied. 


\section{References:}

Agius, R. 2013. Is Malta's experiment of public sector co-operatives a potential model for others to follow and is this model working?, Unpublished M.A. Public Policy Dissertation, University of Malta.

Arado, J. 2017. CDA against repealing of tax exemption of coops. Sunstar. Available at: http://www.sunstar.com.ph/article/138524/.

Baldacchino, P.J. 2017. External auditing and corporate governance perspectives in a small state: the case of Malta. PhD Thesis, Loughborough Business School, University of Loughborough, Chapter 12 pp. 352-69. Available at: https://dspace.lboro.ac.uk/dspacejspui/bitstream/2134/32602/3/Thesis2017-Baldacchino.pdf

Baldacchino, P.J. and Camilleri, N. 2013. The financing of Maltese cooperatives. The Accountant, Spring, 24-27.

Baldacchino, P.J., Falzon M. and Grima, S. 2017. The co-operative regulatory framework in a small state: Reviewing the alternatives. Journal of Accounting, Finance and Auditing Studies, 3(2), 16-43.

Banking Act. 1994. Chapter 371 of the Laws of Malta.

Bezzina, F. and Grima, S. 2012. Exploring factors affecting the proper use of derivatives: an empirical study with active users and controllers of derivatives. Managerial Finance, 38(4), 414-434.

Bezzina, F., Grima, S., Mamo, J. 2013. Risk Management Practices Adopted by financial firms in Malta. Managerial Finance, 38(4), 414-434.

Briguglio, L. 1995. Small island developing states and their economic vulnerabilities. World Development, 23(9), 1615-1632.

Central Co-operative Fund Regulations. 2016. Subsidiary Legislation 442.03.

Co-operative Societies Act. 2001. Chapter 442 of the Laws of Malta.

Constitution of Malta. 1964. Constitution of Malta.

Delia, E.P. 2004. Address of Welcome. In Delia, E.P. et al. The Future of Co-operatives in the Agriculture \& Fisheries Sectors. APS Bank Publication, Blata l-Bajda: Media Centre Print.

Delia, E.P. 2006. Economic Efficiency, Solidarity, and the Co-operative Model: Lessons for Maltese Co-ops. In Delia, E.P. et al. Reconsidering Co-operatives: Lessons for Maltese Co-ops. APS Bank Publication, Blata l-Bajda, Malta: Media Centre Print.

Ellwood, W. 2012. Can co-operative crowd out capitalism? Available from: http://newint.org/features/2012/07/01/co-operatives-international-year/.

Fabri, D. 2006. The Co-operative Societies Act 2001 - A Comment on the Recent Reforms in Maltese Co-operatives Law. In Fabri, D. et al. Reconsidering Co-operatives: Lessons for Maltese Co-ops. APS Bank Publication, Blata 1-Bajda, Malta: Media Centre Print.

Galea, F. 2012. L-Istorja tal-Koperattivi f'Malta, Stamperija tal-Gvern, Marsa.

Henrÿ, H. 2012. Guidelines for Co-operative Legislation (3rd ed). International Labour Organization, Geneva.

Income Tax Act. 1949. Chapter 123 of the Laws of Malta.

International Co-operative Alliance (ICA). 1995. Statement on the Co-operative Identity, International Co-operative Alliance. Geneva, References.

International Co-operative Alliance (ICA). 2013. Blueprint for a Co-operative Decade, International Co-operative Alliance, Geneva. Available at: 
http://ica.coop/sites/default/files/media items/ICA\%20Blueprint\%20-\%20Final\%20\%20Feb\%2013\%20EN.pdf.

International Labour Organisation (ILO). 2002. R193 - Promotion of Cooperatives Recommendation, No. 193. Available at: http://www.ilo.org/dyn/normlex/en/f?p=NORMLEXPUB:12100:0::NO::P12100_ILO CODE:R193.

Juhász, J. 2004. FAO's Approach to Developing Farmers' Cooperatives and its Relevance to Malta. In Juhasz, J. et al. The Future of Co-operatives in the Agriculture \& Fisheries Sectors. APS Bank Publication, Blata 1-Bajda, Malta: Media Centre Print.

King, R. 1993. The geographical fascination of islands. In Lockhart, D.G., Drakakis-Smith, D. and Schembri, J. (Eds), The Development Process in Small Island States, Routledge, London, pp. 13-37.

Koperattivi Malta (KM). 2010. Consultation Paper on Co-operative Societies, Koperattivi Malta, Malta. Available at: www.yesitmatters.com/Koperattivi_Malta_Consultation_Paper_on_Cooperatives_201 $\underline{0 . p d f}$.

Koperattivi Malta (KM). 2014. Proposti ta' Koperattivi Malta dwar Tibdil fil-Ligi talKoperattivi u Kummenti ohra dwar Policies.

Malta Co-operative Federation (MCF). 2014. Recommendations on changes to the Maltese Legislation effecting Co-operative Societies. Malta Co-operative Federation, Malta. Available at: http://maltacooperativefederation.coop/wpcontent/uploads/2014/04/MCF_proposals_t o_Coop_Legislation_amendments_2014.pdf.

Münkner, H.H. 2010. Report of the Development of Co-operatives in Malta. Marburg, Germany.

Prakash, D. 2003. The Principles of Cooperation: A look at the ICA cooperative identity statement. Available at: http://www.uwcc.wisc.edu/info/intl/daman_prin.pdf. 